\title{
Fourwing Saltbush (Atriplex canescens)
}

\section{Propagation Techniques}

\author{
LOREN E. WIESNER AND WALLACE J. JOHNSON
}

Fourwing saltbush [Atriplex canescens (Pursh) Nutt] is crosspollinated and therefore has a wide genetic base. This characteristic makes it impossible to establish genetically similar research plots from seed. Consequently plots must be established from cuttings taken from desirable parent plants. The purpose of this study was to develop a method for rapid propagation of fourwing saltbush and to outline procedures for handling the propagules after rooting.

Highest percentage of rooted cuttings was obtained when green succulent cuttings were soaked for 24 hours in a complete nutrient solution before being dipped in a woody species rooting compound and placed in a mist-bench for 5 weeks. Rooted cuttings should be transplanted into flats containing $75 \%$ sand and $25 \%$ peat and watered every 4-5 days to obtain maximum growth.

Fourwing saltbush [Atriplex canescens (Pursh) Nutt] is an important browse species in the southwestern United States. Livestock and wild game readily eat the leaves and stems of this plant, which contain from 14-16\% protein (Gamrath 1972). It is also a drought tolerant shrub and is valuable for soil conservation purposes.

Stand establishment from seed has been hampered because of low utricle fill, seed dormancy, and poor germination. Research to date has concentrated on the causes of low utricle fill.

Because fourwing saltbush is cross-pollinated and has a wide genetic background, it is necessary to establish experimental plots from cuttings of a desirable parent plant. A propagation technique developed by Ellern (1972) for Atriplex halimus L. requires 8 weeks or longer to establish an acceptable root system and survival of cutting was approximately $76 \%$. The purpose of this study was to develop a rapid method of propagating fourwing saltbush and to determine procedures for handling the cuttings after rooting.

\section{Materials and Methods}

\section{General Procedures}

Materials used for these studies were obtained from the Bridger Plant Materials Center (PMC) and Wade Creek near Bridger, Mon-

\footnotetext{
Authors are associate professor and former graduate student, Plant and Soil Science Department, Montana State University, Bozeman 59715

The study is a contribution from Plant and Soil Science Department, Montana State University, Bozeman, in cooperation with the Soil Conservation Service, Bridger Plant Materials Center, Bridger, Montana. It is published with the approval of the Director of Montana Agricultural Experiment Station as Journal Series 671. (Received February 23, 1975.)

Manuscript received April 21, 1976.
}

tana. A female plant, from accession P 15585, was selected from a planting at the Bridger PMC for its ability to produce a large number of utricles. The selected female plant was transplanted into the greenhouse at Montana State University, Bozeman. Additional female cuttings were obtained from randomly selected plants growing at Wade Creek. Similarly, a male plant, of a Wyoming selection being grown at the Bridger PMC, was selected for its ability to produce pollen. The male plant was staked and cuttings were taken from it for propagation studies.

Cutting length for all studies was approximately $7.6 \mathrm{~cm}$ long and $1-3 \mathrm{~mm}$ in diameter. Cuttings were propagated in a mist-bench in the University greenhouse (Fig. 1). Frequency and duration of mist was controlled by evaporation of water from the surface of an electronic leaf, which simulates the evaporation of moisture from plant foliage.

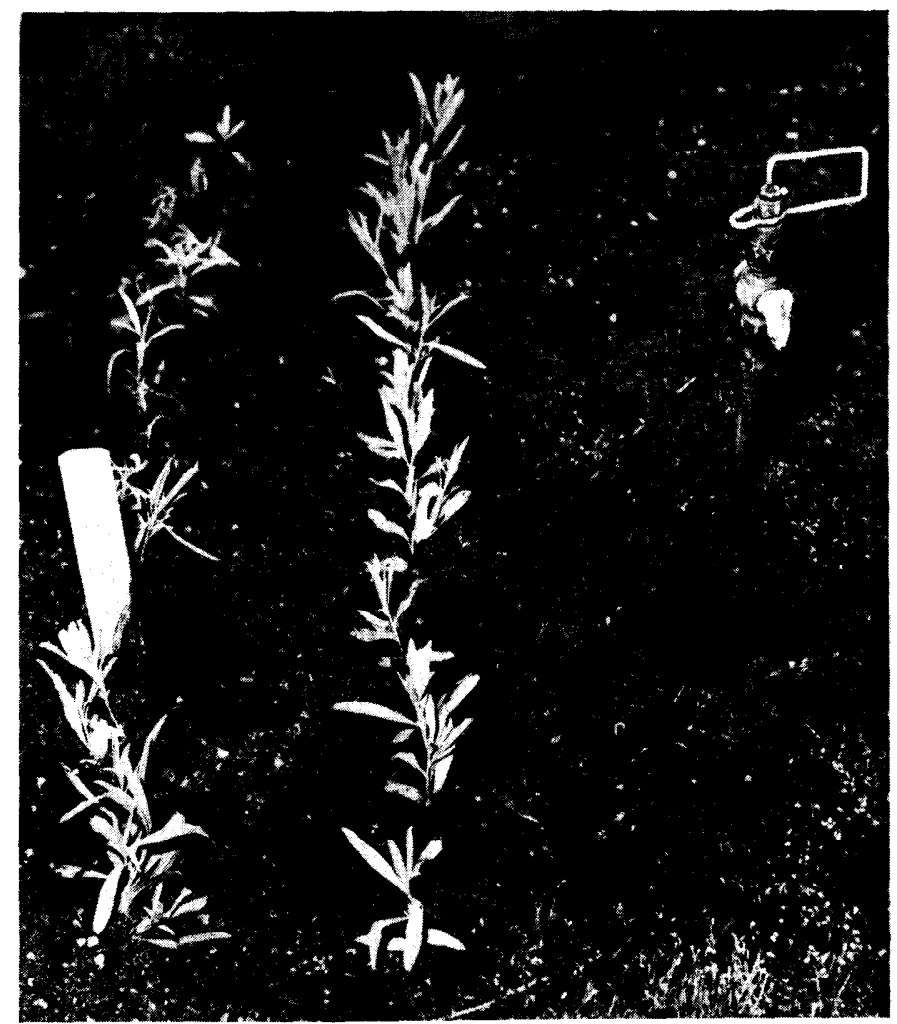

Fig. 1. Fourwing saltbush cuttings being rooted in a mist-bench containing soil which is composed of $50 \%$ sand and $50 \%$ peat. 
Soil temperature in the mist-bench was maintained at $20^{\circ} \mathrm{C}$ at a depth of $10 \mathrm{~cm}$. Mist-bench soil was composed of $50 \%$ sand and $50 \%$ peat (hereafter referred to as the standard mixture). A portion of the bench contained vermiculite with a small portion of sand.

\section{Evaluation of Published Propagation Techniques}

Propagation techniques similar to those developed by Ellern (1972) were evaluated using the tips of young branches of female fourwing saltbush plants. Cuttings were placed in the greenhouse mist-bench on June $15,1972$.

Cuttings were divided into two groups, one group was placed in the portion of the bench containing the standard mixture and the other group placed in the portion of the bench containing vermiculite. Cuttings were observed at weekly intervals for 8 weeks, at which time the percentage of rooting and root development were evaluated. Upon removal from the mist-bench, rooted cuttings were transplanted into pots containing $50 \%$ sand and $50 \%$ peat. These pots remained on the mist-bench for 2-3 days before being transferred to another location in the greenhouse.

\section{Modification of Propagation Techniques}

Three related studies were conducted in an attempt to improve propagation procedures for fourwing saltbush.

Cuttings used for the first study were young succulent branches from the female plant growing in the greenhouse. Cuttings were placed in the mist-bench January 10, 1973, in the portion containing the standard mixture. Before cuttings were placed in the mist-bench, they were dipped in one of two types of rooting compound. The two rooting compounds were (1) for woody species, and (2) for nonwoody species.

Rooting of cuttings was evaluated weekly after the first 4 weeks in the mist-bench. Rooted cuttings were transplanted to flats containing $75 \%$ coarse sand and $25 \%$ peat. Flats containing cuttings remained on the mist-bench for 2-3 days after transplanting, and were then moved to another section of the greenhouse which provided adequate light and a temperature of $20-25^{\circ} \mathrm{C}$. Transplants were watered every $4-5$ days; but not over watered.

A second study was conducted using plant material of a phenology stage similar to that used in the first study; however, cuttings were placed in Hoagland's complete nutrient solution for 24 hours before planting in the mist-bench. After soaking, cutting tips were treated with Hormodin \#2, a wood species rooting compound $(0.3 \%$ indolebutryric acid, Merck Chemical Company ${ }^{1}$ ) and then placed in the mistbench. Rooted cuttings were handled in a similar manner as described in the previous study, except that 3 weeks after transplanting half of the cuttings were clipped to remove the tip of the central axis.

A third study was conducted using male cuttings to evaluate procedures developed in the two previous studies. Propagation procedures and phenological stage of cuttings were similar to those used in the second study.

\section{Results}

\section{Evaluation of Published Propagation Techniques}

Eight weeks were required to develop rooted fourwing saltbush propagules when using the propagation techniques published by Ellern (1972). A typical root system consisted of 3 to 5 branches. The highest percent of rooted cuttings was obtained with the standard mixture (Table 1). None of the cuttings placed in the vermiculite rooting media developed roots.

Rooted cuttings which were transplanted into pots containing $50 \%$ sand and $50 \%$ peat suffered from excess moisture and failed to grow properly.

\section{Modification of Propagation Techniques}

Cuttings treated with the woody species rooting compound developed adequate root systems (Fig. 2) and $80 \%$ of these cuttings rooted when placed in the standard mixture of the mist-

\footnotetext{
'Mention of trademark or proprietary product does not imply its approval to the exclusion
} of other products that may also be suitable.
Table 1. Comparison (\%) of fourwing saltbush cuttings rooted in two medias using Ellern's technique.

\begin{tabular}{lcc}
\hline \hline Media & $\begin{array}{c}\text { Number of } \\
\text { cuttings }\end{array}$ & $\begin{array}{c}\text { Cuttings rooted } \\
(\%)\end{array}$ \\
\hline Standard mixture & 50 & 25 \\
Vermiculite & 50 & 0 \\
\hline
\end{tabular}

bench, as compared to $40 \%$ rooting for cuttings treated with the nonwoody rooting compound (Table 2). Five weeks were required for satisfactory rooting. Rooted cuttings which were transplanted into flats containing $75 \%$ sand and $25 \%$ peat developed rapidly and did not suffer from excess moisture; however, these plants were sparsely branched.

Table 2. Comparison (\%) of fourwing saltbush cuttings rooted when treated with rooting compounds for woody species and nonwoody species.

\begin{tabular}{lcc}
\hline \hline Compounds & $\begin{array}{c}\text { Number of } \\
\text { cuttings }\end{array}$ & $\begin{array}{c}\text { Cuttings rooted } \\
(\%)\end{array}$ \\
\hline Woody species & 75 & 80 \\
Nonwoody species & 75 & 40 \\
\hline
\end{tabular}

Soaking cuttings in a complete nutrient solution in addition to the techniques used above improved rooting by $9 \%$ (Table 3 ). Clipping the tip of the central axis of rooted cuttings increased lateral branching as compared to unclipped cuttings (Fig. 3).

Techniques similar to those used for rooting female cutting were successful in rooting male cuttings as $93 \%$ of the male cuttings were rooted.

Table 3. Comparison (\%) of fourwing saltbush cuttings rooted when soaked and when not soaked in complete Hoagland solution.

\begin{tabular}{lcc}
\hline Treatment & $\begin{array}{c}\text { Number of } \\
\text { cuttings }\end{array}$ & $\begin{array}{c}\text { Cuttings rooted } \\
(\%)\end{array}$ \\
\hline Soaked & 45 & 90 \\
Not soaked & 45 & 81 \\
\hline
\end{tabular}

\section{Discussion}

Propagation techniques developed by Ellern for Atriplex halimus were unsatisfactory for fourwing saltbush. These

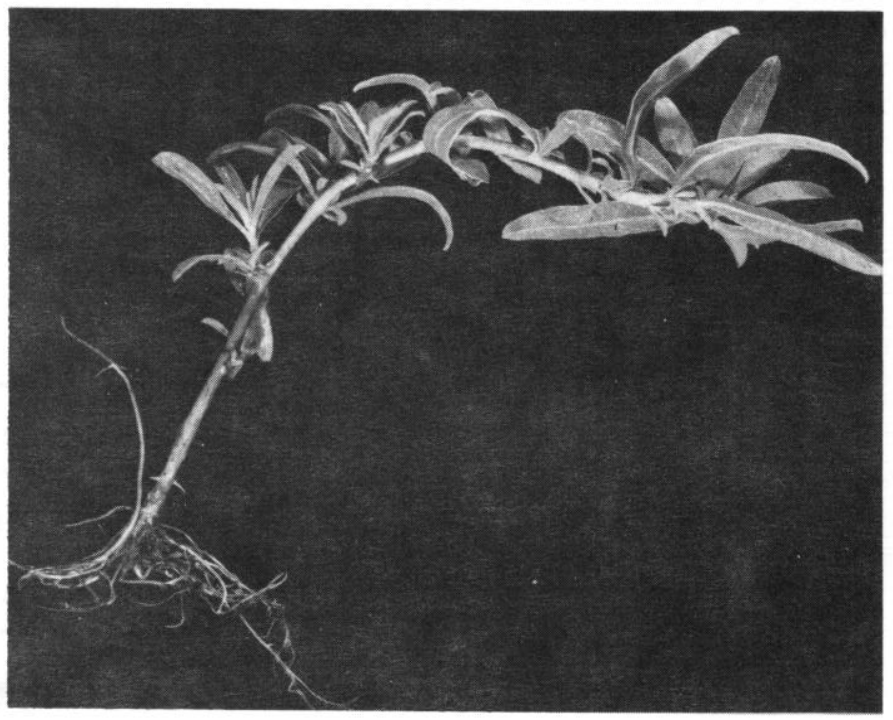

Fig. 2. Typical root system of a fourwing saltbush cutting which had been treated with a woody species rooting compound. 


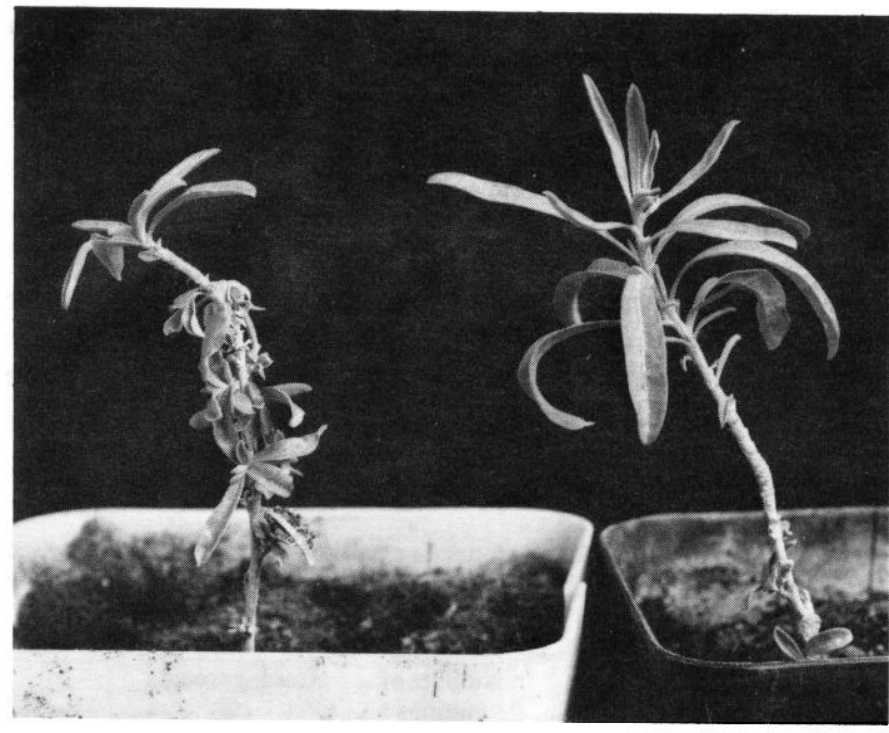

Fig. 3. Rooted fourwing saltbush cuttings; the central axis of the cutting on the right was clipped 3 weeks after transplanting and the cutting on the left was not clipped

techniques required 8 weeks for rooting and then only three to five secondary roots were developed.

Soaking cuttings in nutrient solution, using a woody species rooting compound and propagating in a mist-bench increased rooting of fourwing saltbush cuttings.

Cuttings which were soaked for 24 hours did not wilt when placed in the mist-bench. The woody species rooting compound was better than the nonwoody compound for succulent fourwing saltbush cuttings. The difference in performance of the rooting compounds may be attributed to the higher level of indolebutyric acid present in the woody species compound. When treating stem ends with the rooting compound, moisten the stems and remove the excess compound before planting. Excessive rooting compound on the stem may damage or kill cuttings.

A mist-bench medium of $50 \%$ sand and $50 \%$ peat was better than vermiculite for rooting. These studies suggest that it is important to keep foliage moist at all times; however, excess moisture in the soil will reduce root development. Improved rooting could also be attributed to a more exact temperature control in the mist-bench. Mixing of the soil surface after 3 weeks will improve aeration and reduce cutting injury due to soil borne pathogens.

Our propagation procedures for fourwing saltbush required 5 weeks for rooting as compared to 8 weeks for Ellern's tech- nique. Transplanting of rooted cuttings to flats containing $75 \%$ sand and $25 \%$ peat provided the best condition for growth. The shock of changing environments was reduced by leaving transplants on the mist-bench for 2-3 days. The soil in flats must contain enough sand to assure proper drainage. Frequency of watering is determined by water holding capacity of the soil, generally plants will need to be watered every 4-5 days. After cuttings have adjusted to the new environment, clip the tip of the central axis. This induces lateral branching and a second clipping may be necessary to promote more branching.

\section{Summary}

The techniques used for propagation of A. halimus were inadequate for propagating fourwing saltbush.

Based on our studies we recommend the following procedures:

1. Use green, succulent plant material and make cuttings $7.6 \mathrm{~cm}$ long and $1-3 \mathrm{~mm}$ in diameter.

2. Soak cutting in a complete nutrient solution for 24 hours at room tempeature.

3. Dip moist cutting in a woody species rooting compound before placing in mist-bench.

4. Mist-bench soil should contain $50 \%$ sand and $50 \%$ peat.

5. Leave cuttings in mist-bench for 5 weeks.

6. Transplant cuttings to flats containing $75 \%$ sand and $25 \%$ peat.

7. Leave transplanted cuttings on mist-bench for 2-3 days.

8. Remove flats from mist-bench and provide adequate light and temperature $\left(20-25^{\circ} \mathrm{C}\right)$.

9. Water flats every $4-5$ days to get optimum growth-do not over water.

10. Prune cuttings $3-4$ weeks after transplanting.

With these propagation techniques rooted cuttings can be obtained within 5 weeks and $93 \%$ of the cuttings in the mist-bench will be rooted.

\section{Literature Cited}

Gamrath, W. G. 1972. The relationship of plant morphology and seed processing to utricle fill and germination of fourwing saltbush [Atriplex canescens (Pursh) Nutt] seed. MS Thesis, Montana State Univ., Bozeman. 44 p.

Gerard, J. B. 1965. Factors and treatments affecting fruit fill, seed germination, and seedling emergence of fourwing saltbush. MS Thesis, New Mexico State Univ., Las Cruces. 57 p.

Ellern, S. V. 1972. Rooting cuttings of saltbush (Atriplex halimus L.). J. Range Manage. 25:154-155.

\title{
CLYDE ROBIN NATIVE SEEDS
}

\author{
Castro Valley, California 94546
}

